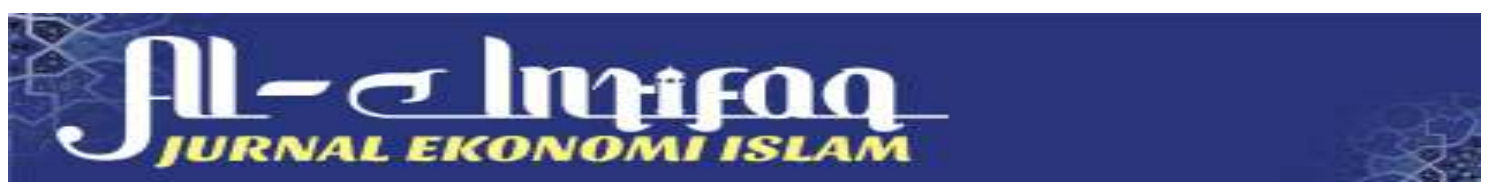

\title{
Pengaruh Pengenaan Pajak Pertambahan Nilai (PPN) Terhadap Daya Beli Konsumen Barang Elektronik Di Pasar Batusangkar
}

\author{
Desy Farina ${ }^{1}$, Revi Candra ${ }^{2}$, Yudi Irawan ${ }^{3}$ \\ Fakakultas Ekonomi dan Bisnis Islam, Institut Agama Islam Negri Batusangkar \\ $\underline{\text { desyfarina65@ymail.com }}{ }^{1}, \underline{\text { revicandra@iainbatusangkar.ac.id }{ }^{2}}$
}

\begin{abstract}
This study aims to determine the effect of VAT imposition on consumer purchasing power of electronic goods in the Batusangkar market. The author uses a type of field research (field research) conducted in the Batusangkar market at an electronics store using a quantitative descriptive approach. The population in this study were consumers of electronic goods in the Batusangkar market. Sampling was carried out using random sampling techniques, the number of samples was determined as many as 50 people from the total population of 100 people. The data collection technique used was a questionnaire. The data analysis technique used to answer the hypothesis in this study is a simple linear regression analysis technique, so it can be seen that the effect of value added tax on consumer purchasing power of electronic goods in the Batusangkar market. This is evidenced by the correlation coefficient between Value Added Tax and Purchasing Power of o.812, which means a positive correlation and has a very strong relationship, meaning that if prices increase, consumer purchasing power will decrease resulting in taxes imposed in the form of VAT will also decrease.
\end{abstract}


Abstrak: Penelitian ini bertujuan Untuk mengetahui pengaruh Pengenaan PPN terhadap daya beli konsumen barang elektronik di pasar Batusangkar. Penulis menggunakan jenis penelitian lapangan (field research) yang dilakukan di pasar Batusangkar pada toko elektronik dengan menggunakan pendekatan Deskriftif Kuantitatif. Populasi dalam penelitian ini adalah konsumen barang elektronik di pasar Batusangkar, pengambilan sampel dilakukan dengan teknik random sampling, jumlah sampel ditentukan sebanyak 50 orang dari jumlah polulasi sebanyak 100 orang. Teknik pengumpulan data yang dipakai adalah dengan menggunakan kuesioner. Teknik analisis data yang digunakan untuk menjawab hipotesis dalam penelitian ini adalah teknik analisis regresi linier sederhana, sehingga dapat diketahui bahwa adanya pengaruh pajak pertambahan nilai terhadap daya beli konsumen barang elektronik di pasar Batusangkar. Hal ini dibuktikan dengan koefisien korelasi antara Pajak Pertambahan Nilai dengan Daya Beli sebesar 0,812 yang bearti korelasi positif dan mempunyai hubungan yang sangat kuat, Artinya jika harga naik maka daya beli konsumen akan menurun mengakibatkan pajak yang dikenekan berupa PPN juga akan menurun.

Kata Kunci : Pajak Pertambahan Nilai, Daya Beli Konsumen

\section{PENDAHULUAN}

Perkembangan ekonomi di dunia membawa konsekuensi terhadap peningkatan aktivitas perdagangan. Adanya sifat bergantung antara satu negara dengan negara lain dalam hal pemenuhan kebutuhan membuat aktivitas perdagangan semakin tidak dapat dipisahkan. Pajak merupakan sumber penerimaan negara yang terbesar yang digunakan dalam meningkatkan pembangunan untuk mewujudkan kesejahteraan masyarakat. Dimana hal tersebut sesuai dengan tujuan dari negara Indonesia. (Israelka, 2011)

Pajak Pertambahan Nilai merupakan salah satu pajak yang memberikan kontribusi cukup besar pada penerimaan suatu Negara. Pajak Pertambahan Nilai yang menggantikan Pajak Penjualan sejak 1 April 1985 yang ditetapkan berdasarkan Undang-Undang Nomor 8 Tahun 1983 sebagaimana telah diubah dengan UU Nomor 42 Tahun 2009 Tentang Pajak Pertambahan Nilai (PPN) Barang dan Jasa dan Pajak Penjualan Atas Barang Mewah (PPnBM). (Noviane, 2015: 133).

Daya beli konsumen selama ini menjadi pendorong pertumbuhan ekonomi yang luar biasa, dengan jumlah penduduk yang besar pemerintah sangat mengandalkan daya beli konsumen (Aktual, 2016). Daya beli merupakan kemampuan seseorang dalam mengkonsumsi suatu produk, daya beli juga mempunyai hubungan erat dengan suatu barang (Amanda, 2019: 13).

Berdasarkan data harga barang Elektronik di Pasar Batusangkar terlihat bahwa adanya peningkatan harga barang elektronik yang disebabkan oleh pajak pertambahan nilai sebesar $10 \%$, dengan adanya peningkatan harga tersebut maka akan menyebabkan daya beli konsumen menurun, sesuai dengan hukum perimintaan "jika harga naik, maka daya beli menurun". 
Dalam beberapa penelitian terdahulu oleh Raja Abdurrahman(2014) dengan judul penelitian Analisis Pengaruh Pajak Pertambahan Nilai (PPN) dan Pajak Penjualan Atas Barang Mewah (PPnBM) terhadap Daya Beli Konsumen Pada Kendaraan Bermotor dijelaskan bahwa ). Dalam penelitian ini, Raja menggunakan penelitian Kuantitatif. Hasil peneitian menunjukkan terdapat pengaruh positif dan signifikan Variabel PPN maupun PPNBM terhadap Variabel Daya Beli Konsumen. Ada juga dalam penelitian lain oleh Novi Darmayanti dengan judul Analisis Perhitungan Pajak Pertambahan Nilai (PPN) Pada Cv. Sarana Teknik Kontrol Surabaya. Hasil penelitian menunjukkan bahwa oleh perusahaan masih belum sesuai dengan perubahan Undang-Undang Perpajakan yang baru, sehingga laba yang diperoleh lebih sedikit karena tarif pajak terlalu besar.

Dalam dikatakan bahwa masalah dalam penelitian ini adalah pengaruh pengenaan PPN terhadap daya beli konsumen barang elektronik di pasar Batusangkar dengan tujuan untuk mengetahui pengaruh pengenaan PPN terhadap daya beli konsumen barang elektronik di pasar Batusangkar.

\section{KAJIAN TEORI Pajak}

Pajak merupakan iuran wajib dari rakyat kepada pemerintah. Namun, karena pajak selalu mengikuti perkembangan zaman, maka banyak para ahli yang memberikan batasan mengenai pajak. Hal ini disebabkan karena pengertian pajak itu sendiri dapat dilihat dari berbagai sudut pandang, baik dari segi penghasilan, segi daya beli, dan segi ekonomi.

Pajak Pertambahan Nilai menurut Undang-Undang No.18 Tahun 2000 yang disempurnakan lagi dalam Undang-Undang No.42 Tahun 2009 adalah Pajak atas konsumsi Barang Kena Pajak (BKP) dan atau Jasa Kena Pajak (JKP) yang dilakukan di dalam Daerah Pabean. Daerah pabean itu sendiri merupakan wilayah teritorial Indonesia.(Mardiasmo, 2016, hal 332)

Adapun Pajak Pertambahan Nilai menganut tarif tunggal yaitu 10\%. Dengan Peraturan Pemerintah, tarif PPN dapat diubah menjadi serendah-rendahnya 5\% dan setinggi-tingginya 15\%. Sedangkan tarif PPN atas ekspor Barang Kena Pajak adalah $0 \%$. Pengenaan tarif $0 \%$, ini bukan berarti pembebasan dari pengenaan Pajak Pertambahan Nilai akan tetapi pajak masukan yang telah dibayar dari barang yang diekspor tetap dapat dikreditkan.

Menurut Undang-Undang Republik Indonesia Nomor 42 Tentang Pajak Pertambahan Nilai Barang dan Jasa dan Pajak Penjualan Atas Barang Mewah Tahun 2009, PPN adalah pajak atas konsumsi barang dan jasa di Daerah Pabean yang dikenakan di setiap jalur produksi dan distribusi . PPN dikenakan disetiap kegiatan mengkonsumsi barang atau jasa di daerah pabean. Secara tidak langsung masyarakat akan dikenakan pajak dalam setiap konsumsinya. Kondisi perekonomian yang belum mapan dan berbeda mengakibatkan turunnya daya beli konsumen Barang Elektronika. (Pramesti dan Supadmi, 2017)

\section{Daya Beli}

Daya beli (Purchasing Power) merupakan kemampuan seseorang dalam mengkonsumsi suatu produk. Daya beli antara satu orang dengan orang lainnya pastilah berbeda. Hal tersebut dapat disebabkan oleh beberapa faktor, seperti dilihat dari status orang tersebut, pekerjaan, penghasilan, dan sebagainya.(Amanda, 2019: 13). 


\section{METODE PENELITIAN}

\section{Jenis Penelitian}

Dalam penelitian ini, jenis penelitian yang digunakan adalah penelitian deskriptif kuantitatif yaitu suatu penelitian yang menggunakan data kuantitatif dimana melalui teknik pengumpulan, pengolahan, penyederhanaan, penyajian dan analisis data, dan memberikan gambaran yang teratur tentang suatu peristiwa melalui observasi (Supardi, 2005 hal 27).

\section{Teknik Analisis Data}

Data dari hasil penelitian yang dikumpulkan, selanjutnya dilakukan analisis terhadap masalah yang dihadapi dengan menggunakan alat bantu statistik. Aplikasi perangkat lunak yang digunakan dalam menganalisis data pada penelitian ini adalah statiscal Products and service Solutions (SPSS) for windows versi 22.0

Metode-metode yang digunakan untuk menganalisis data dan menguji hipotesis dalam penelitian ini adalah sebagai berikut:

\section{Uji Validitas dan Reliabilitas}

Uji Validitas

Uji validitas dilakukan untuk memastikan bahwa masing-masing item dalam instrument penelitian mampu mengukur variabel yang ditetapkan dalam penelitian ini. Sebuah instrument dikatakan valid, jika mampu mengukur apa yang dinginkan dan mengungkapkan data variabel yang diteliti secara tepat (Ghozali, 2005 hal 45)..

Uji Reliabilitas

Uji reabilitas adalah alat untuk menguji konsistensi jawaban responden. Suatu kuesioner dikatakan reliable jika jawaban seseorang terhadap pertanyaan adalah konsisten dari waktu ke waktu.(Ghozali, 2005 hal 41)

\section{Uji Normalitas}

Uji normalitas bertujuan untuk menguji apakah dalam model regresi, variabel pengganggu atau residual memiliki distribusi normal. (Imam Ghozali, 2005 hal 147).

\section{Uji Hipotesis}

Dalam membuktikan kebenaran uji hipotesis yang diajukan digunakan uji statistic terhadap output yang dihasilkan dari persamaan regresi, uji statistic ini meliputi:

\section{Uji korelasi}

Uji korelasi merupakan suatu teknik statistik yang dipergunakan untuk mengukur kekuatan hubungan 2 variabel dan juga untuk dapat mengetahui bentuk hubungan antara 2 variabel tersebut dengan hasil yang sifatnya kuantitatif

Untuk dapat memberikan interpretasi terhadap hasil koefisien maka dapat digunakan tabel:

Tabel 1

Interval Dan Tingkat Hubungan

\begin{tabular}{|l|l|}
\hline Interval Koefisien & Tingkat Hubungan \\
\hline $0,00-0,199$ & Sangat Rendah \\
\hline $0,20-0,399$ & Rendah \\
\hline $0,40-0,599$ & Sedang \\
\hline $0,60-0,799$ & Kuat \\
\hline $0,80-1,000$ & Sangat Kuat \\
\hline
\end{tabular}

Sumber: (Sugiyono, 2018: 287) 


\section{Uji signifikansi parameter individual (uji statistik $t$ )}

Uji t digunakan untuk mengetahui seberapa besar pengaruh dari variabelvariabel bebas secara individual dapat menerangkan variasi variabel dependen. (Gozali, 2005 hal 85)

\section{Uji koefisien Determinasi $\left(r^{2}\right)$}

Koefisien determinasi bertujuan untuk mengukur seberapa jauh kemampuan model dapat menjelaskan variasi variabel dependen. Dalam pengujian hipotesis pertama koefisien determinasi dilihat dari besarnya $r$ Square $\left(\mathrm{r}^{2}\right)$ untuk mengetahui seberapa jauh variabel bebas, yaitu PPN mempengaruhi daya beli konsumen.(Ghozali, 2005 hal 83)

\section{Analisis Regresi Linear Sederhana}

Regresi adalah bentuk hubungan fungsional antara variabel-variabel, sedangkan analisis regresi adalah mempelajari bagaimana antar variabel saling berhubungan. Analisis regresi linear sederhana digunakan untuk sebuah variabel independen $X$ dan sebuah variabel dependen $Y$.

Adapun bentuk umum persamaan regresi sederhana yag digunakan dalam penelitian ini adalah sebagai berikut:

$$
\begin{aligned}
& \mathbf{Y}=\mathbf{a}+\mathbf{b} \mathbf{X} \\
& \text { Dimana : } \\
& \mathrm{Y}=\text { Daya beli konsumen } \\
& \text { a } \quad=\text { Konstanta } \\
& \mathrm{b}=\text { koefisien } \\
& \text { X }=\text { variabel bebas }(\mathrm{PPN})(\text { Umar, 2011: 92) }
\end{aligned}
$$

\section{HASIL DAN PEMBAHASAN \\ Hasil Penelitian \\ Uji Validitas dan Reliabilitas}

1. Uji Validitas

Tabel 2

Hasil Uji Validitas Variabel PPN

\begin{tabular}{|c|c|c|}
\hline $\begin{array}{c}\text { Item } \\
\text { Pertanyaan }\end{array}$ & Sig. & Keterangan \\
\hline PPN1 & $\mathbf{0 , 0 0 0}$ & Valid \\
\hline PPN2 & $\mathbf{0 , 0 0 0}$ & Valid \\
\hline PPN3 & $\mathbf{0 , 0 0 0}$ & Valid \\
\hline PPN4 & $\mathbf{0 , 0 0 0}$ & Valid \\
\hline PPN5 & $\mathbf{0 , 0 0 0}$ & Valid \\
\hline PPN6 & $\mathbf{0 , 0 0 0}$ & Valid \\
\hline PPN7 & $\mathbf{0 , 0 0 0}$ & Valid \\
\hline PPN8 & $\mathbf{0 , 0 0 0}$ & Valid \\
\hline
\end{tabular}

Sumber: Data diolah SPSS 22, 2020

Berdasarkan hasil tabel 4.2 diatas menunjukan bahwa semua pertanyaan dari variabel indevenden Pajak Pertambahan Nilai adalah valid. Hal ini seperti terlihat dari semua pertanyaan diatas dikatakan valid karena memiliki nilai signifikasi dibawah 0,05 . 
Tabel 1

Hasil Uji Validitas Variabel DBK

\begin{tabular}{|c|c|c|}
\hline Item Pertanyaan & Sig. & Keterangan \\
\hline DBK1 & $\mathbf{0 , 0 0 0}$ & Valid \\
\hline DBK2 & $\mathbf{0 , 0 0 0}$ & Valid \\
\hline DBK3 & $\mathbf{0 , 0 0 0}$ & Valid \\
\hline DBK4 & $\mathbf{0 , 0 0 0}$ & Valid \\
\hline DBK5 & $\mathbf{0 , 0 0 0}$ & Valid \\
\hline DBK6 & $\mathbf{0 , 0 0 0}$ & Valid \\
\hline DBK7 & $\mathbf{0 , 0 0 0}$ & Valid \\
\hline DBK8 & $\mathbf{0 , 0 0 0}$ & Valid \\
\hline
\end{tabular}

Sumber: Data diolah SPSS 22, 2020

Berdasarkan hasil tabel 4.3 diatas menunjukan bahwa semua pertanyaan dari variabel devenden Daya Beli Konsumen adalah valid. Hal ini seperti terlihat dari semua pertanyaan diatas dikatakan valid karena memiliki nilai signifikasi 0,000 atau dibawah dibawah 0,05.

\section{Uji Reliabilitas}

Tabel 2

Hasil Uji Reliabilitas

\begin{tabular}{|l|c|c|}
\hline \multicolumn{1}{|c|}{ Validitas } & $\begin{array}{c}\text { Cronbach } \\
\text { Alpha }\end{array}$ & N of items \\
\hline Pajak Pertambahan Nilai & 0,823 & 8 \\
\hline Daya Beli Konsumen & 0,903 & 8 \\
\hline
\end{tabular}

Sumber: Data diolah SPSS 22, 2020

Berdasarkan data pada tabel 4.4 diatas, instrumen Pajak Pertambahan Nilai dan Daya Beli konsumen. Masing-masing memiliki nilai Cronbach Alpha 0,823 dan 0,903 . Semua instrumen dinyatakan reliabel karena memiliki nilai Cronbach Alpha diatas 0,60

\section{Uji Normalitas}

\section{Gambar 1}

Grafik Normal P-Plot 


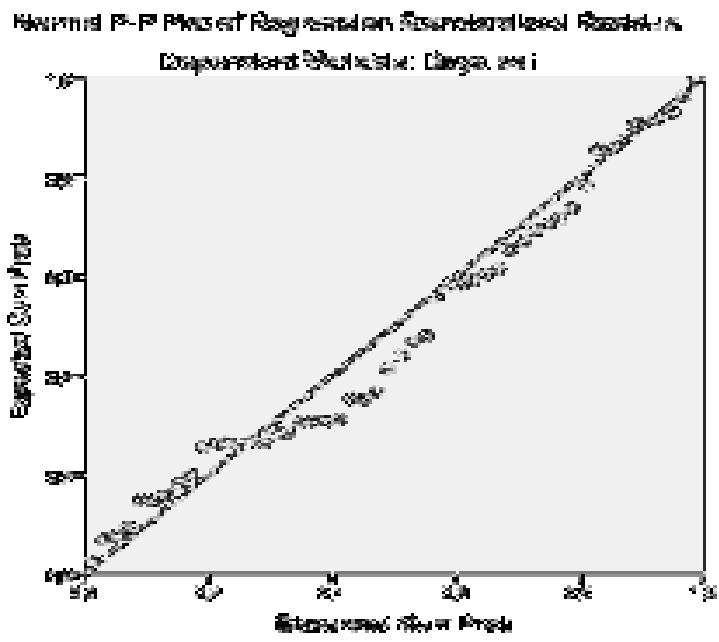

Sumber: Data diolah SPSS 22, 2020

Berdasarkan grafik diatas adanya persebaran data (titik) pada sumbu diagonal yang sangat mendekati garis diagonal. Pedoman uji normalitas mengatakan bahwa jika persebaran data (titik) mengikuti atau mendekati garis diagonal, maka data penelitian berdistribusi normal. Melihat hal tersebut, penelitian ini bisa disimpulkan memenuhi uji normalitas.

Tabel 5

Uji Normalitas

One-Sample Kolmogorov-Smirnov Test

\begin{tabular}{|ll|r|}
\hline \multicolumn{2}{|c|}{ Validitas } & $\begin{array}{r}\text { Unstandardi } \\
\text { zed Residual }\end{array}$ \\
\hline N & & 50 \\
Normal Parametersa,b & Mean &, 0000000 \\
& Std. & 3,23475622 \\
& Deviation &, 113 \\
Most Extreme & Absolute &, 113 \\
Differences & Positive &,- 074 \\
& Negative &, 113 \\
Test Statistic & &, $134 c$ \\
Asymp. Sig. (2-tailed) & & \\
\hline
\end{tabular}

Sumber: Data diolah SPSS 22, 2020

Berdasarkan data diatas nilai dari Asymp.Sig. (2-tailed) sebesar 0,13 , sehinggan dapat dikatakanbahwa data yang digunakan berdistribusi normal, karena memiliki nilai signifikasi yang besar dari $0,05(0,13>0,05)$

\section{Uji Hipotesis}

\section{Uji Koefisien Korelasi}

Untuk mengetahui pengaruh pengenaan pajak pertambahan nilai terhadap daya beli konsumen digunakan uji koefisien korelasi yaitu sebuah analisis yang digunakan untuk menyelidiki hubungan dua variabel atau lebih diperoleh hasil uji SPSS versi 22 sebagai berikut: 
Tabel 6

Uji Korelasi

Correlations

\begin{tabular}{|ll|r|r|}
\hline \multicolumn{1}{|c|}{ Validitas } & $\begin{array}{c}\text { Pajak } \\
\text { pertambahan } \\
\text { nilai }\end{array}$ & $\begin{array}{c}\text { Daya } \\
\text { beli }\end{array}$ \\
\hline $\begin{array}{l}\text { Pajak Pearson } \\
\text { pertambahan nilai }\end{array}$ & 1 &, $812^{* *}$ \\
& Correlation & &, 000 \\
& Sig. (2-tailed) & 50 & 50 \\
\hline Daya beli & Pearson &, $812^{* *}$ & 1 \\
& Correlation &, 000 & \\
& Sig. (2-tailed) & 50 & 50 \\
\hline
\end{tabular}

Sumber: Data diolah SPSS 22, 2020

Berdasarkan Output dari tabel 4.6 SPSS diatas koefisien korelasi adalah sebesar 0,812. Ini berarti koefisien Pajak Pertambahan Nilai mempunyai hubungan yang sangat kuat terhadap Daya Beli Konsumen. Berdasarkan tabel korelasi.

\section{Uji Statistik T}

Uji t dilakukan untuk mengetahui apakah variabel indevenden (Pajak Pertambahan Nilai) berpengaruh secara signifikan atau tidak terhadap variabel dependen (Daya Beli Konsumen).

Jika nilai $\mathrm{t}$ hitung $>\mathrm{t}$ tabel, maka Ho ditolak dan Ha diterima artinya signifikan dan jika nilai $\mathrm{t}$ hitung $<\mathrm{t}$ tabel, maka Ho diterima dan Ha ditolak artinya tidak signifikan. Berdasarkan nilai profitabilitas dengan alpha $=0,05$, jika profitabilitas $>0,05$, maka Ho diterima dan jika profitabilitas $<0,05$, maka Ho ditolak. Hasil uji t dapat dilihat pada tabel berikut:

\section{Tabel 7}

Uji T

\begin{tabular}{|c|c|c|c|c|c|}
\hline \multirow[b]{2}{*}{ Model } & \multicolumn{2}{|c|}{$\begin{array}{l}\text { Unstandardized } \\
\text { Coefficients }\end{array}$} & $\begin{array}{c}\text { Standardiz } \\
\text { ed } \\
\text { Coefficient } \\
\text { s }\end{array}$ & \multirow[b]{2}{*}{$\mathrm{t}$} & \multirow[b]{2}{*}{ Sig. } \\
\hline & $\mathrm{B}$ & Std. Error & Beta & & \\
\hline 1 (Constant) & 3,186 & 2,763 & & 1,153 & ,255 \\
\hline $\begin{array}{l}\text { Pajak pertambahan } \\
\text { nilai }\end{array}$ & ,935 & ,097 & 812 & 9,624 & ,000 \\
\hline
\end{tabular}

Sumber: Data diolah SPSS 22, 2020

Setelah dilakukan pengujian hipotesis menggunakan uji t diperoleh nilai $\mathrm{t}$ hitung $=9.624$ sedangkan nilai kritis menurut tabel, dengan menggunakan rumus $\mathrm{t}$ a df $\mathrm{n}-2$ yaitu 0,05 df 50-2 = 48 ( $\mathrm{n}$ adalah jumlah sampel dan $\mathrm{k}$ adalah jumlah variabel indevenden). Maka diperoleh $t$ tabel sebesar 1,677. Karena $t$ hitung lebih besar dari $\mathrm{t}$ tabel $(9.624>1,677)$. Maka keputusan Ho ditolak Ha diterima. Dapat disimpulkan bahwa Pajak Pertambahan Nilai berpengaruh 
signifikan terhadap Daya Beli Konsumen barang elektronik di pasar Batusangkar.

\section{Koefisien Determinasi $\left(\mathbf{r}^{2}\right)$}

Koefisien determinasi adalah angka atau indeks yang digunakan untuk mengetahui besarnya sumbangan suatu variabel atau lebih (varibel bebas, X) terhadap variansi naik turunnya (variabel yang terikat, Y), atau koefisien determinasi menjelaskan proporsi untuk menentukan terjadinya persentase variansi antara variabel $X$ yang menyebabkan perubahan variabel $\mathrm{Y}$, maka dapat dilihat pada tabel dibawah ini yang terdapat pada kolom R-Square

Tabel 8

Korelasi

\begin{tabular}{|r|c|r|r|r|}
\hline Model & R & R Square & $\begin{array}{c}\text { Adjusted R } \\
\text { Square }\end{array}$ & $\begin{array}{c}\text { Std. Error of } \\
\text { the Estimate }\end{array}$ \\
\hline &, $812^{\mathrm{a}}$ &, 659 &, 652 & 3,268 \\
\hline
\end{tabular}

Sumber: Data diolah SPSS 22, 2020

Berdasarkan tabel di atas nilai $R$ Square adalah 0,659. Hasil perhitungan tersebut menjelaskan bahwa variable Pajak Pertambahan Nilai dapat memberikan pengaruh terhadap aya Beli Konsumen sebesar 65,9\%. Sedangkan sisanya sebesar $34,1 \%$ dipengaruhi oleh variable lainnya di luar variable yang tidak ada dalam penelitian.

\section{Analisis Regresi Linear Sederhana}

Berdasarkan persamaan regresi, maka penulis membuat penjabaran persamaan penelitian sebagai berikut:

\section{Tabel 9}

Koefisien Regresi Linear Sederhana

Coefficients $^{\mathrm{a}}$

\begin{tabular}{|c|c|c|c|c|c|}
\hline \multirow[b]{2}{*}{ Model } & \multicolumn{2}{|c|}{$\begin{array}{c}\text { Unstandardized } \\
\text { Coefficients }\end{array}$} & \multirow{2}{*}{$\begin{array}{c}\text { Standardi } \\
\text { zed } \\
\text { Coefficien } \\
\text { ts } \\
\text { Beta }\end{array}$} & \multirow[b]{2}{*}{$\mathrm{T}$} & \multirow[b]{2}{*}{ Sig. } \\
\hline & B & $\begin{array}{l}\text { Std. } \\
\text { Error }\end{array}$ & & & \\
\hline $1 \quad$ (Constant) & 3,186 & 2,763 & & 1,153 & 255 \\
\hline $\begin{array}{l}\text { Pajak } \\
\text { pertambahan } \\
\text { nilai }\end{array}$ & ,935 & ,097 & 812 & 9,624 &, 000 \\
\hline
\end{tabular}

Sumber: Data diolah SPSS 22, 2020

Dari data diatas menunjukan bahwa nilai sig untuk Pajak Pertambahan Nilai adalah 0,000 $(\mathrm{p}<0,05)$ maka dari itu hipotesis diterima artinya variabel pajak 
Pertambahan Nilai berpengaruh signifikan terhadap Daya Beli Konsumen koefisien regresi variabel PPN b=0,935 dengan konstanta sebesar 3,186. Dengan demikian diperoleh persamaan regresi linear sebagai berikut:

$$
\begin{aligned}
& Y=a+b X \\
& Y=3,186+0,935
\end{aligned}
$$

Koefisien regresi pada Pajak Pertambahan Nilai sebesar 0,935, hal ini berarti jika variabel Pajak Pertambahan Nilai bertambah satu satuan maka daya beli konsumen bertambah sebesar 1,935. Kesimpulan nya adalah bahwa setiap kenaikan Pajak Pertambahan Nilai akan menyebabkan kenaikan Daya Beli Konsumen, begitu juga sebaliknya setiap penurunan Pajak Pertambahan Nilai akan menyebabkan penurunan Daya Beli Konsumen.

\section{Pembahasan}

Dari pengolahan data diperoleh data validitas antara Pajak Pertambahan Nilai dengan Daya Beli Konsumen Sebesar 0,000 yang berarti data itu valid karena memiliki nilai signifikasi dibawah 0,05 .

Hasil penelitian ini menunjukan bahwa variabel PPN memiliki t hitung 9.264 bila dibandingkan dengan $t$ tabel 1,677. Maka $t$ hitung $9.624>t$ tabel 1,677. Dengan demikian hipotesis Ho ditolak Ha diterima. Maka dapat dinyatakan bahwa Pajak Pertambahan Nilai berpengaruh signifikan terhadap Daya Beli Konsumen barang elektronik di pasar Batusangkar.

Dari pengolahan data diperoleh koefisien korelasi antara PPN dengan Daya Beli Konsumen sebesar 0,812 yang berarti korelasi positif dan mempunyai hubungan yang sangat kuat. Artinya jika harga naik maka daya beli konsumen akan menurun, mengakibatkan pajak yang dikenekan berupa PPN juga akan menurun.

Pajak Pertambahan Nilai berpengaruh positif dan signifikan terhadap daya beli konsumen barang elektronik di pasar Batusangkar, dimana jika harga tinggi maka akan mempengaruhi daya beli menurun, disinilah terjadi hubungan antara PPN dengan daya beli konsumen. a=0,05 dengan koefisien regresinya sebesar 0,935 yang artinya bahwa setiap kenaikan PPN sebesar satu kali maka Daya Beli meningkat sebesar 1,935. Dimana hasil ini sesuai dengan teori yang diungkapkan mahendra, 2018. Nilai R Square sebesar 0,659 atau 65,9\% hal ini berarti bahwa besar pengenaan Pajak Pertambahan Nilai terhadap Daya Beli Konsumen sebesar 65,9\% sedangkan sisanya $34,1 \%$ disebabkan oleh faktor lain.

\section{KESIMPULAN DAN SARAN}

\section{Kesimpulan}

Penelitian ini bertujuan untuk mengetahui pengaruh Pajak Pertambahan Nilai terhadap Daya Beli Konsumen, maka kesimpulan dari hasil penelitian adalah sebagai berikut:

Dari pengolahan data diperoleh data validitas antara pajak pertambahan nilai dengan daya beli konsumen Sebesar 0,000 yang berarti data itu valid karena memiliki nilai signifikasi dibawah 0,05. Artinya pajak pertambahan nilai berpengaruh terhadap daya beli konsumen.

Dari hasil Uji Reliabilitas, dapat diketahui diketahui bahwa instrumen pajak pertambahan nilai dan daya beli konsumen masing-masing memiliki nilai Cronbach 
Alpha 0,823 dan 0,903. Semua instrumen dinyatakan reliabel karena memiliki nilai Cronbach Alpha diatas 0,60.

Dari hasil Uji Normalitas, dapat diketahui bahwa adanya persebaran data (titik) pada sumbu diagonal yang sangat mendekati garis diagonal. Pedoman uji normalitas mengatakan bahwa jika persebaran data (titik) mengikuti atau mendekati garis diagonal, maka data penelitian berdistribusi normal. Melihat hal tersebut, penelitian ini bisa disimpulkan memenuhi uji normalitas.

Dari pengolahan data diperoleh koefisien korelasi antara PPN dengan Daya Beli Konsumen sebesar 0,812 yang berarti korelasi positif dan mempunyai hubungan yang sangat kuat. Artinya jika harga naik maka daya beli konsumen akan menurun, mengakibatkan pajak yang dikenekan berupa PPN juga akan menurun. Dari hasil uji determinasi $\mathrm{r}^{2}$ output model summary di ketahui nilai koefisiennya sebesar 0,659. Hasil perhitungan tersebut menjelaskan bahwa variabel pajak pertambahan nilai dapat memberikan pengaruh terhadap daya beli konsumen barang elektronik sebesar $65,9 \%$. Sedangkan sisanya sebesar $34,1 \%$ dipengaruhi oleh variabel lainnya yang tidak ada dalam penelitian ini.

Dari Hasil pengujian $t$ (uji $t$ ) antara variabel PPN dengan daya beli menunjukkan nilai sebesar $\mathrm{t}$ hitung $9.624>\mathrm{t}$ tabel 1,677 $(\mathrm{df}=48)$, dengan nilai signifikan 0,000 yang lebih kecil dari taraf signifikasi 0,05 yang digunakan, koefisien regresi variabel PPN sebesar $b=0,935$ dengan konstanta sebesar 3,186, maka dapat disimpulkan bahwa hipotesis alternative ( $\mathrm{Ha}$ ) yang menyatakan bahwa Pajak Pertambahan Nilai berpengaruh positif dan signifikan terhadap daya beli konsumen barang elektronik di pasar Batusangkar.

\section{Saran}

Berdasarkan hasil pembahasan dan kesimpulan yang diperoleh, maka ada beberapa saran sebagai masukan, yaitu:

\section{Bagi peneliti selanjutnya}

1. Penelitian selanjutnya diharapkan dapat menambahkan variabel indevenden lainnya atau menambahkan variabel moderating guna mengetahui variabel lain yang dapat mempengaruhi variabel devenden.

2. Penelitian selanjutnya diharapkan dapat menambah jumlah sampel penelitian serta memperluas sampel penelitian, bukan hanya di Batusangkar tetapi juga di daerah lainnya, sehingga dapat diperoleh hasil penelitian dengan tingkat generalisasi yang lebih tinggi.

3. Penelitian selanjutnya diharapkan dapat menggunakan metode penelitian yang berbeda seperti metode wawancara langsung kepada responden untuk memperoleh data yang lebih berkualitas

\section{Bagi konsumen atau masyarakat}

Jika masyarakat ingin membeli suatu barang maka harus memperhatikan pula tambahan pengenaan pajaknya, karena kemampuan daya beli masyarakat berbeda-beda, hal ini disebabkan kondisi perekonomian yang belum mapan. 


\section{DAFTAR PUSTAKA}

Abdurrahman, Raja. (2014). Analisis Pengaruh Pajak Pertambahan Nilai (PPN) dan Pajak Penjulan Atas Barang Mewah (PPnBM) Terhadap Daya Beli Konsumen Pada Kendaraan Bermotor. Jurnal Raja Abdurrahman, 2014

Agung, Mulyo. (2009). Perpajakan Indonesia seri PPn, PPnBM, dan PPh Badan, teori dan Aplikasi. Jakarta: Mitra Wacana Media.

Arikunto, Suharsimi. (2002). Prosedur Penelitian Suatu Pendekatan. Jakarta: Rineka Cipta.

Claudya, Noviane. (2015). Analisis Pengaruh Pajak Pertambahan Nilai (PPN) dan Pajak Penjulan Atas Barang Mewah (PPnBM) Terhadap Daya Beli Konsumen Pada Kendaraan Bermotor. Jurnal Berkala Ilmiah Efisiensi Volume 15 No. 05 Tahun 2015

Darmayanti, Novi. (2012). Analisis Perhitungan Pajak Pertambahan Nilai (PPN) pada CV. Sarana Teknik Kontrol Surabaya. jurnal Manajemen dan Akuntasi Volume 1, Nomor 3, Desember 2012

Ghozali, Imam. (2005). Aplikasi Analisis Multivariate dengan Program SPSS Edisi 3. Semarang. Badan Penerbit Universitas Diponegoro

Jefta, Israelka. (2011). Analisis Penerapan Pajak Pertambahan Nilai, E-Jounal Economic vol.3 No.5, 2

Mardiasmo. (2016). Perpajakan . Yogyakarta: C.V Andi Offset. (2009). Perpajakan edisi revisi. Yogyakarta: C.V Andi Offset.

Nugroho, S. (2015). Perilaku Konsumen: konsep dan dan implikasi untuk penelitian pemasaran. Jurnal Berkala Ilmiah Efisiensi Volume 15 No. 05 Tahun 2015, 135.

Pandiangan, Liberty. (1993). Pajak Pertambahan Nilai (PPN). Jakarta: PT Rineka Cipta.

Pramesti dan Supadmi. (2017). Pengeruh PPN, PPnBM, dan PKB Tarif Progresif pada Daya Beli Konsumen, E-Jurnal Akuntansi Univetsitas Udayana, 18, pp. 674-704

Purwanto, A.E dan Ratih, D.S. 2017. Metode Penelitian Kuantitatif. Yogyakarta : GAVA MEDIA

Resmi, Siti (2011). Perpajakan Teori dan Kasus. Jakarta: Salemba Empat

Setiawati, Anastasya, Dwi. (2009). Perpajakan Indonesia Konsep, Aplikasi dan penuntun praktis. Yogyakarta: C.V Andi Offset.

Sukardji, Untung. (2011). Pokok-pokok Pajak Pertambahan Nilai Indonesia. Jakarta: Rajawali Pers.

Sumarsan, Thomas. (2017). Perpajakan Indonesia. Jakarta: PT Indeks Permata Putri Media.

Supramono. (2010). Perpajakan Indonesia. Yogyakarta: C.V Andi Offset.

Supriadi. (2005). Metode Penelitian Ekonomi dan Bisnis. Yogyakarta: IKAPI 
Waluyo. (2007). Perpajakan Indonesia. Jakarta: Salemba Empat. 